\title{
Demonetisation: It's Impact on Economy and Environment
}

\author{
Reena Yadav \\ Assistant Professor, Deen Dayal Upadhyaya College, New Delhi, India
}

\begin{abstract}
The study tries to frame the reason behind demonetisation that was announced by Prime Minister $\mathrm{Mr}$. Narendra Modi $8^{\text {th }}$ November 2016. Increasing terrorism, inflation in prices, the attacks in Jammu \& Kashmir were the reasons that indicated the need for some strict and serious decisions like that of demonitisation. All the above activities cannot be done in the absence of funds and the source of funding was from black money. Black money is not only an illegal activity in itself but is also a backbone to all other such illegal and unwanted activities. This paper further tries to look at the impact of demonetisation on environment in various ways.
\end{abstract}

Keywords-Demonetisation, legal tender, black money, environment, inflation, economy.

\section{INTRODUCTION}

Demonetisation is the act of stripping a currency unit of its status as legal tender. It occurs whenever there is a change of national currency: The current form or forms of money is pulled from circulation and retired, often to be replaced with new notes or coins. Sometimes, a country completely replaces the old currency with new currency.

The opposite of demonetisation is remonetisation, in which a form of payment is restored as legal tender.

BREAKING DOWN DEMONITISATION

There are multiple reasons why nations demonetise their local units of currency:

- to combat inflation

- to combat corruption and crime (counterfeiting, tax evasion)

- to discourage a cash-dependent economy

- to facilitate trade

The most recent example of demonetisation is of Rs. 500 and Rs. 1000 notes by an announcement made by the Prime Minister Mr. Narendra Modi on the evening of $8^{\text {th }}$ November 2016.

\section{METHODOLOGY}

This research paper is based on secondary data collected from books, journals and websites. The study is descriptive and analytical in nature.

The objectives of this study are:

1. To understand the meaning and concept of demonetisation.

2. To study the reasons behind a decision like demonetisation.

3. To understand the impact of demonetisation on black money and the economy as a whole.

4. To understand the benefits of demonetisation on various aspects of the economy.

5. To study the highs and lows of demonetisation.

6. To study the impact of demonetisation on environment.

\section{LITERATURE REVIEW}

The term demonetisation can be defined as ceasing of a currency from its status of being a legal tender.

Our Indian economy consists of two types of cash:

- Accounted cash: Cash can become legal only when it is accounted either with the tax or bank deposit.

- Unaccounted cash: Whichever type of cash reaches out of the reach of tax or bank deposits, is stated as unaccounted cash or illegal cash.

Demonetisation can be said as an unprecedented move to flush out and counterfeit uncounted money. Demonitisation can be said to be as one of the ways to "kill" the black economy and curb the generation of the black money. But thanks to such great improper execution of statutory tax provisions, ineffective search, seizures, surveys and enforcement and rare prosecutions due to legal loopholes, the black money economy still thrives.

The reason behind the governments' move of demonetisation was to inculcate two reasons:

$>$ To eliminate the counterfeit currency used by smugglers and terrorists. 
$>$ The government wanted to destroy the black economy by forcing the "de-hoarding" of cash heed by those black money earners and generators.

Demonetisation has led to immediate and long-term impact on real estate, reduction in deposit rates by the banks, reduction in lending rates by banks, fall in India's financial markets.

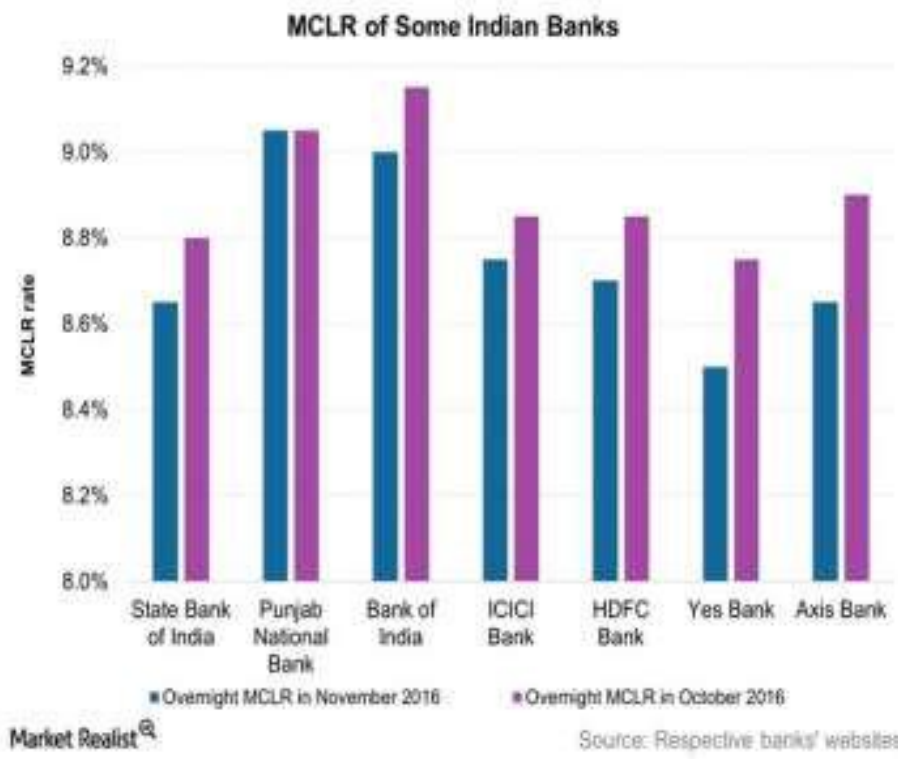

MCLR of Some Indian Banks

\section{HISTORY OF DEMONITISATION:}

The act of demonetisation is not new to India. The move to make currency illegal overnight has happened earlier. By putting a cap on the money that one is able to deposit without coming under the scanner and the notice of the Income Tax Department, the government aimed at investigating the root of tax evasions and black money income generators.

1. January 1946 - Currency notes of Rs. 500, Rs.1000 and Rs.10000 demonetised.

Government strikes at "black capitalists"

The front page of Indian express from that day read that the move was taken with aim of to curb black marketing. The repercussions were similar to those of today, people dying of shock, exceptionally long queues outside the banks and the middle-class population being at major hit.

\section{January 1978}

"High currency being demonetized"

Notes of Rs.1000, Rs.5000 and Rs.10000 demonetised. The "Janta Dal" demonetised high currency notes, such a historic move with a perspective to curb black money transactions. It was termed as "an act to provide in the public interest for demonetisation of certain high denominations bank notes and for matters connected therewith or incidental thereto.
3. November 2016

"The great cash cleanup"

Unprecedented move to flush out counterfeit and unaccounted money. The report titled 'Measure to tackle black money in India and Abroad', while discussing demonetisation as one of the ways to kill the black economy or curb generations of black money, found it impracticable despite its noble aims. Apparently, it revealed that in both the instances of demonetisation, 1946 and 1948, less than 15\% high currency notes were exchanged. Critics mostly indicated that the lacking of black money menace had a lot to do with the implication of the existing laws and prevention measures. The current phase of demonetisation has evoked that it would only increase the cost associated with currency note production as more of the currency needs to be printed and circulated for distributing the same amount and volume of currency. The government demonetisation may fail to win the war against black money.

\section{REAL REASONS BEHIND PM MODI'S DEMONETISATION MOVE}

\section{Maoists hit}

Chhattisgarh, Telengana, Andhra Pradesh and Orissa had 413 (2014) witnessed deaths in the North Eastern states with Assam being the highest; these deaths are a result of the Maoist activities. According to sources, Maoists had stashed over Rs.7000 crore at their dumps in Bastar region. Now all of that is nothing but a bundle of papers.

The demonetisation move has hit them hard, and their activities have totally come to stand still.

\section{No stone-pelting in $\mathbf{J} \& \mathbf{K}$}

Since demonetisation, incident of stone-pelting on armed forces has not been reported. The citizens of Kashmir have lauded this bold move by the NDA government, as first time in decades; the valley has remained peaceful for 5 consecutive days.

\section{Corrupts burning cash}

Honest citizens are ready to do their bit for the country (to face hassles of currency exchange) and face this move with patience, as they know this bold move will make India- a world power. The corrupt people, who had stashed unaccounted cash in huge amounts, are spending their nights, burning their cash.

4. Kirana shops/Panwalas installing debit card machines 
People have started installing debit card machines and Paytm for cashless transactions, thus improving transparency in market. People have realised the benefits of having a cashless economy and like the government, the citizens too, are working towards the betterment of the country.

\section{Huge opportunities for mobile wallets}

Digitization is the way to future. Post demonetisation steep rise in the use of mobile wallets have been reported. The private sector online payments have reported a significant rise in the usage patterns by their users. If we manage to tap even half of the cash transactions, then India's GDP will reach to new highs.

\section{Drug peddlers in Punjab hit}

The only state to have suffered the drugs menace is Punjab. The drug peddlers have run back into their rat holes post demonetisation. The drugs business is the most important, in a shadow economy. The drugs business has completely stopped in the state, as transactions were done only in cash.

\section{MISS IN DEMONETISATION}

1. GDP

Growth slowed as demonetisation affected all trade and commerce aspects, demand supply and increased uncertainty.

2. Uncertainty

Uncertainty increased as the firms and households were unsure of the economic impact and its implications of demonetisation. The government expects to strengthen the credibility if demonetisation is accompanied by complementary measures and brings early and full remonetisation.

3. Demonetisation will further hit the economy The GDP growth would be even lower because of demonetisation. 1\% reduction in GDP means a loss of Rs.1,50,000 Crore and had been repeatedly questioning the benefits of withdrawal of Rs.500 and Rs. 1000 notes.

\section{IMPACT ON THE ENVIRONMENT}

Immediately after the declaration on $9^{\text {th }}$ November by Prime Minister Modi Ji that the old currency of 500 and 1000 is no more the legal tender, we all could see its impact. There were cases where people buried and burned all their illegal old currency just for the sake of not being caught with that old currency. This burring did have an impact on the environment as these notes are made with the help of certain chemicals. And burring such notes led to spread of those chemicals into our surroundings as these chemicals came into direct contact of soil thereby polluting the area and its ground water. Few people did declare their illegal money but that percentage was low. Further, printing of new notes require paper and for producing that paper there is a need to cut down the trees thereby impacting the environment tremendously.

\section{CONCLUSION}

Although the decision of demonetisation was the matter of great inconvenience and discomfort to all but its overall impact to the economy and country as a whole was very good. Everything comes at a cost so was the cost for demonetisation; the long queues outside the ATMs and banks, increased working hours of the bank employees, reduced sales of the shopkeepers and also reduced GDP of the economy due to the quarter in which demonetisation took place. Also with everything good, came some negative and adverse effects, one of them being its adverse effect on environment. Even though demonetisation was not a complete success but it proved to be a good decision to a great extent.

\section{REFERENCES}

[1] https://thefearlessindian.in/real-reason-behind-pmmodis-demonetzation-move/

[2] marketrealist.com/2016/11/impact-demonetizationindias-inflation/

[3] www.investopedia.com/terms/d/demonetization.asp 